2013s-42

Doing R\&D in a Closed or Open Mode: Dynamics and Impacts on Productivity

Julio Miguel Rosa, Pierre Mohnen

\begin{tabular}{c}
\hline Série Scientifique \\
Scientific Series
\end{tabular}

Montréal

November 2013

(C) 2013 Julio Miguel Rosa, Pierre Mohnen. Tous droits réservés. All rights reserved. Reproduction partielle permise avec citation du document source, incluant la notice (C).

Short sections may be quoted without explicit permission, if full credit, including (C) notice, is given to the source.
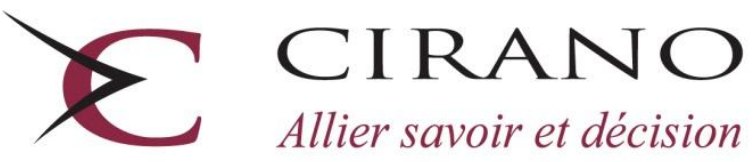

Allier savoir et décision

Centre interuniversitaire de recherche en analyse des organisations 


\section{CIRANO}

Le CIRANO est un organisme sans but lucratif constitué en vertu de la Loi des compagnies du Québec. Le financement de son infrastructure et de ses activités de recherche provient des cotisations de ses organisations-membres, d'une subvention d'infrastructure du Ministère de l'Enseignement supérieur, de la Recherche, de la Science et de la Technologie, de même que des subventions et mandats obtenus par ses équipes de recherche.

CIRANO is a private non-profit organization incorporated under the Québec Companies Act. Its infrastructure and research activities are funded through fees paid by member organizations, an infrastructure grant from the Ministère de l'Enseignement supérieur, de la Recherche, de la Science et de la Technologie, and grants and research mandates obtained by its research teams.

\section{Les partenaires du CIRANO}

\section{Partenaire majeur}

Ministère de l'Enseignement supérieur, de la Recherche, de la Science et de la Technologie

Partenaires corporatifs

Autorité des marchés financiers

Banque de développement du Canada

Banque du Canada

Banque Laurentienne du Canada

Banque Nationale du Canada

Banque Scotia

Bell Canada

BMO Groupe financier

Caisse de dépôt et placement du Québec

Fédération des caisses Desjardins du Québec

Financière Sun Life, Québec

Gaz Métro

Hydro-Québec

Industrie Canada

Investissements PSP

Ministère des Finances et de l'Économie

Power Corporation du Canada

Rio Tinto Alcan

State Street Global Advisors

Transat A.T.

Ville de Montréal

\section{Partenaires universitaires}

École Polytechnique de Montréal

École de technologie supérieure (ÉTS)

HEC Montréal

Institut national de la recherche scientifique (INRS)

McGill University

Université Concordia

Université de Montréal

Université de Sherbrooke

Université du Québec

Université du Québec à Montréal

Université Laval

Le CIRANO collabore avec de nombreux centres et chaires de recherche universitaires dont on peut consulter la liste sur son site web.

Les cahiers de la série scientifique (CS) visent à rendre accessibles des résultats de recherche effectuée au CIRANO afin de susciter échanges et commentaires. Ces cahiers sont écrits dans le style des publications scientifiques. Les idées et les opinions émises sont sous l'unique responsabilité des auteurs et ne représentent pas nécessairement les positions du CIRANO ou de ses partenaires.

This paper presents research carried out at CIRANO and aims at encouraging discussion and comment. The observations and viewpoints expressed are the sole responsibility of the authors. They do not necessarily represent positions of CIRANO or its partners. 


\title{
Doing R\&D in a Closed or Open Mode: Dynamics and Impacts on Productivity*
}

\author{
Julio Miguel Rosa ${ }^{\dagger}$, Pierre Mohnen
}

\begin{abstract}
Résumé/abstract
Les firmes sont tiraillées entre deux façons de faire de la R-D. D'un côté, elles préfèrent faire la R-D de manière ouverte (en faisant faire de la R-D extramuros ou même en vendant des services de R-D) afin de bénéficier d'externalités de connaissance et de complémentarités entre la R-D interne et la R-D externe. D'un autre côté, elles préconisent de faire la R-D en mode fermé (en faisant de la recherche intramuros et en se finançant sur base de fonds propres ou de subventions) afin de minimiser les fuites de connaissance. Dans cette étude, nous examinons la dynamique des choix quant à la façon de faire de la recherche et l'effet de ces choix sur les rendements de celle-ci. Nous nous basons sur les données de l'enquête de Statistique Canada sur la recherche et développement dans l'industrie canadienne (RDIC) pour la période 1997-2006. La dimension panel de la base de données nous permet de contrôler pour l'hétérogénéité individuelle inobservée dans l'estimation d'un modèle Logit multinomial dynamique à partir de la méthode du maximum de vraisemblance simulé.
\end{abstract}

Mots clés : persistance, modèle Logit multinomial dynamique, données panel, maximum de vraisemblance simulé, innovation ouverte.

On the one hand, firms prefer to perform $R \& D$ in an open mode (letting $R \& D$ be performed extramurally or even selling their $R \& D$ services) to benefit from knowledge spillovers and complementarities between internal and external $R \& D$. On the other hand, they may also like to perform $R \& D$ in a closed mode (funding and executing their $R \& D$ intramurally) to minimize outgoing externalities. We examine the dynamic process by which firms change the way of doing $R \& D$ and how these strategic choices of doing $R \& D$ affect their productivity growth. This study is based on the Statistics Canada Research and Development in Canadian Industry survey (RDCI), which collects data on $R \& D$ performed in the business sector in Canada. The paper is based on data for the period 1997 to 2006. The panel dimension of the data allows to control for unobserved characteristics of $R \& D$ performers by estimating a multinomial Logit model with unobserved heterogeneities using maximum simulated likelihood (MSL) method.

Key words: R\&D; State Dependence; Dynamic Multinomial Logit; Panel-data; Maximum Simulated Likelihood; Open Innovation.

Codes JEL : C35, L23, 032, 033

\footnotetext{
"The ideas expressed in this article are those of the authors and do not reflect the opinions of Industry Canada or Government of Canada. The authors thank Théophile Azomahou for his incisive comments.

${ }^{\dagger}$ Industry Canada, Economic Research and Policy Analysis Branch, Canada. E-mail: JulioMiguel.Rosa@ic.gc.ca

${ }^{*}$ UNU-MERIT, Maastricht University, the Netherlands, and CIRANO, Canada. E-mail:

Mohnen@Merit.unu.edu
} 


\section{Introduction}

Research and development $(\mathrm{R} \& \mathrm{D})$ is an important activity in the innovation process. But, it implies to overcome a number of barriers. The cost of performing R\&D is a major barrier for many firms. Another one is the ability for firms to retain all the benefits resulting from efforts invested in research [Arrow (1962)]. What is often overlooked is that a firm must first have sufficient absorptive capacity to recognize the value of new information, assimilate it and apply it to commercial ends [Cohen and Levinthal (1990)]. Some research projects are fairly complex and require multidisciplinary teams. Such teams are not always readily available within firms and are established through partnerships and collaborative work.

In other words, the decision to contract out $R \& D$ knowledge services or to perform $R \& D$ in house, the "Make and Buy decision" as it is known in the literature, represents one of the more complex choices facing a firm's managers [Leiblein and Dalsace (2002)]. Contracting-out R\&D knowledge services allows firms to benefit from knowledge transfers [Katsoulacos and Ulph (1998)].

Firms face the following dilemma. On the one hand, firms have incentives to perform R\&D in an open mode (perform R\&D for, or have it performed by, others firms) by attempting to maximize knowledge externalities and complementarities in R\&D. On the other hand, firms have incentives to perform R\&D in a closed mode (perform $\mathrm{R} \& \mathrm{D}$ for themselves intramurally) and minimize outgoing externalities through investments in knowledge protection [Cassiman and Veugelers (2002)].

Obviously, external technological knowledge cannot easily be integrated to a firm that performs $R \& D$ in a closed mode, because of the difficulties of implementing the external know-how [Veugelers (1997)]. As pointed out by Cohen and Levinthal (1990) and Piga and Vivarelli (2004), R\&D performers need to have a stock of prior knowledge (absorptive capacity) to effectively incorporate and assimilate externalities into their decisions. To overcome this type of potential technological market failure, the firm can modify its behavior to reflect the assimilation of new knowledge. For policy makers it is important to know how this potential market failure in "research and development activities" can affect innovation and competition.

To respond to this concern we want to address two questions: First, how do firms evolve in the way they organize their R\&D activities? Is there a dynamic, evolutionary process under way that determines the choice between make and buy? Second, is there a difference in the rates of return to R\&D depending on the way the R\&D is conducted? Although, many studies have examined the factors that influence the make and buy decision [(Arora and Gambardella, 1990; Hanel, 2000; Cassiman and Veugelers, 2002; Beneito, 2003; Miravete and Pernias, 2006; Cesaroni, 2004; Rosa and Mohnen, 2006)], no study so far, to our knowledge, has examined the transitional dynamics in the organization of $\mathrm{R} \& \mathrm{D}$, and few have addressed the performance implications of these decisions [(Cohen and Levinthal, 1990; Veugelers, 1997; Antonelli et al., 2013)]. The firm's choice for outsourcing affects innovativeness and productivity according to Baziliauskas and Mathewson (2007). Our study will be based on Canadian firm data originating from 
Statistics Canada RDCI (Research and Development in Canadian Industry) survey. With a full sample of 125,568 firm-years it constitutes one of the largest databases used so far to analyse R\&D in Canada. We shall use the panel data dimension to control for unobserved heterogeneity when estimating the dynamics in the organization of $\mathrm{R} \& \mathrm{D}$.

The paper is organized as follows. In the following section, we extend the traditional concept of the make and buy decision. Data sources and descriptive statistics are described in section 3 . In sections 4 and 5 we set up the empirical model and present the estimation results for firms' transitions in the manner of performing $R \& D$. In section 6 we present the estimated impact of $R \& D$ organization on economic performance. Section 7 summarizes and concludes. 


\section{Organizational choices of $R \& D$}

\subsection{An extension beyond the traditional make and buy decisions}

Typically, a firm has to consider two types of decisions regarding technological funding. Either the acquisition of knowledge from $R \& D$ is internal or external. It can perform the $R \& D$ itself, in a closed environment or it may choose to meet its needs by purchasing R\&D services from other institutions. This decision in the literature has been known as the make and buy decision [(Williamson, 1991; Gambardella, 1992)]. The exploration of the combination of these two types of knowledge acquisition allows firms to benefit from complementarities in technological competence. The external R\&D acquisition can improve the firms' performance from internal efforts [Belderbos and Lokshin (2006)]. The two decisions can, however, also be viewed as substitutes [Fernandez-Bagues (2003)]. The decision to organize the R\&D within the firm or to go for open innovation depends on internal versus external costs and benefits [(Chesbrough et al., 2006; Drechsler and Natter, 2012; Garriga et al., 2013)]. But a firm may also do $R \& D$ for other institutions. We shall define the following three ways of doing R\&D based on the source and destination of payments for R\&D:

1- Make is when intramural R\&D work is performed and funded within the reporting unit (it includes federal grants but excludes parents, affiliated and subsidiary companies). 2- Sell is when R\&D is performed by the reporting unit but funded by others institutions (including parents, affiliated and subsidiary companies). 3- Buy is when R\&D work is performed by other institutions (including parents, affiliated and subsidiary companies) and paid by the reporting unit. These three basic modes of doing R\&D may be combined. This study focuses on four possible strategies:

- The firm can make R\&D for itself (Strat_m)

- The firm can make R\&D for itself and buy R\&D services (Strat_mb)

- The firm can make R\&D for itself, buy and sell R\&D services (Strat_mbs)

- The firm can make R\&D for itself and sell R\&D services (Strat_ms).

The observed $R \& D$ amounts related to these strategies for each firm performing $R \& D$ in the RDIC database [Statistics Canada (2006)] are described in the next section. We won't distinguish between domestic and international $R \& D$ flows, but we shall distinguish between firms under domestic or foreign control. We exclude the following three exclusive strategies: Sell (s); Buy (b) and Sell-Buy (sb). Conceptually, a firm cannot sell something that was not produced in the first place. The Sell-Buy(sb) strategy conceptually means that a firm could make money just by proposing its services as an intermediary between a customer interested in purchasing R\&D output and a vendor who has performed this $R \& D$. The population covered in this study concerns only R\&D performers, in fact, the situation where a 
firm buys R\&D exclusively from others institutions (b) is unlikely. It appears reasonable to assume that a firm that buys some $R \& D$ has a minimum of technological absorptive capacity that it has acquired from doing some R\&D itself. These exclusions eliminate 2,733 observations from our data set representing less than $2.0 \%$ of the total observations for the period 1997 to 2006.

\subsection{Transitions between $R \& D$ strategies}

The rationale that leads a firm to carry out $R \& D$ consists of a complex sequence of decisions. A firm adopts one or the other R\&D strategy based on numerous considerations. Whether or not the firm is able to protect and appropriate its knowledge and the benefits of its $R \& D$ investment is an important consideration. The benefits associated with the internalization of R\&D such as the coordination across technological activities within the production system or the technological interdependencies could motivate the firm to carry out its R\&D intramurally [Leiblein and Dalsace (2002)]. By contrast, the risk associated with the research and the time required to developed the technology could motivate the firm to acquired R\&D extramurally [(Teece, 1992; Williamson, 1991)]. Finally, the firms that engage in R\&D activities for a long-term period learn from their past experiences on R\&D [Piga and Vivarelli (2004)]. In this sense, this process acquired by experience can be viewed as a dynamic mechanism by which a performer of $R \& D$ switches from one $R \& D$ strategy to another. This mechanism describes the trajectory of organizational learning in the way of performing $R \& D$. This learning process leads the firm to adopt different R\&D strategies over time. For example, one possible trajectory for R\&D strategies could be described as follows:

1. For immediate needs, firms initiate occasional R\&D projects internally (Make). At this stage of development, the R\&D performers have not yet acquired a sufficient level of specialization and know-how to benefit from externalities. A further development is the R\&D performance on a continuous basis. At this stage, R\&D is still performed internally.

2. The second stage comes with the realization that not all $R \& D$ knowledge can be generated internally. The firm acquires extramural knowledge in the form of $R \& D$ purchases while following its in-house research activities (Make and Buy).

3. At the third stage, the firm achieves a level of expertise in $R \& D$ sufficient to offer $R \& D$ services while continuing its own research activities (Make, Buy and Sell).

4. Finally, the firm is completely specialized. It dedicates all its research effort to its own development, and it even sells R\&D services (Make and Sell). Sometimes, selling R\&D services becomes the main economic activity. Such a stage is also observed amongst spin-off firms and emerging firms. 
This trajectory suggests that the current state of R\&D strategy influences the probability of switching to another state in the future. The determinants of transitions between $R \& D$ strategies will be the object of our investigation. The transition from one strategy of doing R\&D to another can be the sign of an internal change in the composition of the firms' scientific staff. It can be an indication that the firm seeks to enlarge its competences by acquiring new knowledge that is not available internally. It can be a sign that the firms seeks to sell its competences. Maintaining the same strategy can mean that the firm does not wish to share its technological knowledge. Some strategies can favor or inhibit technological diffusion. We propose to conduct a state dependence analysis of $R \& D$ strategies to estimate the determinants and the probabilities of transition between strategies.

\subsection{R\&D strategies and firm' performance}

Research and development can increase a firm's productivity by improving the quality of its products and processes, but also by diminishing the costs of the existing products and processes [Hall et al. (2010)]. The return on an R\&D investment may differ depending on how the firm acquires knowledge. The firm could be interested in sharing its $R \& D$ activities or not. Breaking down $R \& D$ activities on the basis of their funding sources, internal or external, could allow us to better understand the influence of the firm's R\&D decision on its economic performance. Our second objective is to examine the influence of the way $\mathrm{R} \& \mathrm{D}$ is performed (open vs. closed mode) on labour productivity growth using a panel of Canadian R\&D performers. With the exception of Leiblein and Dalsace (2002) and Lokshin and Carree (2008) the relation between the internal and external strategies of R\&D expenditures on the rate of labour productivity growth has not been deeply explored; in particular this issue has not been addressed simultaneously in manufacturing and in services. Using the same analytical approach as in Fors (1997) and Lokshin and Carree (2008), we shall estimate the returns for different combinations of $\mathrm{R} \& \mathrm{D}$ expenditures on labour productivity growth.

\section{Database and descriptive statistics}

\subsection{The database}

This study is based on Statistics Canada Research and Development in Canadian Industry Survey, which collects data on the entire R\&D performed in the business sector in Canada. The Statistics Canada database is constructed using two sources: an annual survey of major $R \& D$ performers, and administrative data. Administrative data come from the Canada Revenue Agency (CRA), providing data on all firms that claimed an R\&D tax credit under the Scientific and Research and Experimental Development tax credit program. The coverage of the survey is national. A questionnaire was sent to all firms performing 
or funding R\&D valued at $\$ 1.5$ million or more. The population of firms covered includes those that reported $\mathrm{R} \& \mathrm{D}$ activities in the previous survey, those that claimed tax relief for $\mathrm{R} \& \mathrm{D}$ work performed, those that reported receiving $R \& D$ contracts or grants, those that are reported by other firms as funding sources or as performers of $\mathrm{R} \& \mathrm{D}$, and those that are identified in newspaper articles or trade journals.

This paper is based on data collected for the period 1997 to 2006. We present cumulative statistics for these ten years. This approach has the advantage of taking into account possible changes in the structure of the industry. In Statistics Canada's industrial R\&D survey, the other institutions with which the reporting unit has had monetary transactions for $R \& D$ purposes complies with the recommendations of the OECD (2002).

The original pooled database contains 138,431 observations (enterprise-years). We cleaned the data for some extreme values. We excluded those that reported only R\&D capital expenditures but no R\&D labor. We also dropped firms with zero or negative revenues (2,667 observations), with zero employees (252 observations), and with a ratio of (revenue/employee) $\leq 4,000 \$$ or a ratio of (revenue/employee) $\geq 1,000,000 \$$ (7,276 observations). Finally, we dropped firms with the improbable strategies Sell (s), Buy (b) and Sell-Buy (sb) (2,668 observations). The final complete sample consists of about 125,568 observations. Because the surveyed units are generally the larger R\&D performers and the behavior of firms may also vary according to their size and persistence in carrying out R\&D activities [Schelling and Gault (2006)], this analysis will be conducted on the following three sub-samples:

- Continuous R\&D performers (balanced sub-sample - 17,300 observations)

- All R\&D performers (unbalanced full sample - 125,568 observations)

- Large R\&D performers (unbalanced sub-sample - 10,079 observations).

The continuous R\&D performers represent enterprises that are observed continuously during the period 1997 to 2006. This sub-sample regroups mature firms with a cumulative experience in R\&D. The second sample includes all R\&D performers. The third sub-sample, the large R\&D performers, includes only the information collected from the surveyed units (that is, from those spending at least 1.5 million of dollars to perform or fund $\mathrm{R} \& \mathrm{D}$ activities).

\subsection{Descriptive statistics}

Since neither the value added nor the hourly wage are available in the RDCI database to construct labour productivity $^{1}$, we measure the firm's performance by the ratio of total revenues over employment $(\mathbf{Q} / \mathbf{L})$, serving as a proxy for labour productivity ${ }^{2}$.

The variables of interest are the $R \& D$ strategies (Strat $\mathbf{j}$ ), where $\mathbf{j}=\mathrm{m}, \mathrm{mb}, \mathrm{mbs}$ and $\mathrm{ms}$. The $R \& D$ strategy is a dummy variable taking value 1 if the firm opts for a given strategy $(j)$ and zero 
otherwise. For the assessment of the returns to $R \& D$, we use the ratio of $R \& D$ expenditures dedicated to strategy (j) to total revenues $\left(\mathbf{E x p}_{-} \mathbf{S t r a t}_{-} \mathbf{j} / \mathbf{Q}\right)$. The population covered by this study is restricted to R\&D performers. The strategies are described in section 2.1. In accordance with Schumpeter (1934), large firms have an advantage in terms of $R \& D$ and innovation due to economies of scale [(Veugelers and Cassiman, 1999; Breschi and Orsenigo, 2000)]. Large firms may also have more financial resources and a better market position than smaller ones, which makes it easier for them to adapt to changing economic conditions [Delacroix and Swaminathan (1991)]. However, large firms may also suffer from organizational inertia and, if they have a strong market position, they may feel less of a need to do R\&D. These capabilities and disadvantages of large firms could influence both their performance and their choices on how to perform their research. Because this analysis is carried out in a dynamic context, we consider the compound annual growth rate of employment $\Delta(\mathbf{L})^{3}$ as a good proxy to capture the growth in the size of the firm. Firms with high R\&D intensity have a higher level of knowledge appropriation (ability to assimilate external knowledge) and are therefore less concerned about the risk of sharing knowledge through external R\&D partnership. In such a situation, the firm might opt for outsourcing its research or doing it in-house. We expect to capture the absorptive capacity by the ratio of R\&D staff to total employment (Absorptive) and its compound annual growth by $\Delta$ (Absorptive). The influencing factors may differ between domestic and foreign-controlled firms (policies supporting R\&D, the tax environment, etc.), but also the importance that they assign to these factors. For example, foreign-controlled firms may seek endowment complementarities in host countries or sell most of their R\&D services to firms in their group. If this is the case, we should observe a difference in the choice of strategies for foreign and domestically-controlled firms. Hence, we consider the country of control as an important factor contributing to the choice between closed and open R\&D. In order to take into account such an effect, we include a dummy variable equal to one if the country of control is Canada (Domestic) and zero otherwise.

The effect of young and dynamic firms is captured by a dummy variable equal to one if the firm's R\&D expenditure is superior to the firm's revenues (Startup). Generally, such firms are very active in research and are in the first stage of a technological development project. For example, in biotechnology and nanotechnology it is common to observe firms with high R\&D expenditure but no profits. Firms of this type are supported by venture capital funds [(Niosi, 2000)] and are very common in the pharmaceutical industry. Usually in the literature, $R \& D$ is disaggregated into private and public R\&D [Levy and Terleckyj (1989)], process and product R\&D [(Link, 1982; Hanel, 2000)] or basic and applied R\&D [(Mansfield,

\footnotetext{
${ }^{1}$ The Survey has been designed to produce national values of R\&D expenditures for the whole of Canada.

${ }^{2}$ In addition, in the rest of this analysis we have used the industrial product price indexes (IPPI 1997=100) from Statistics Canada (Catalogue 62-011-X) to deflate the firms' revenues.

${ }^{3}$ The compound annual growth rate $(\mathrm{CAGR})=\left[\left(\frac{X_{t_{n}}}{X_{t_{o}}}\right)^{\frac{1}{\left(t_{n}-t_{0}\right)}}-1\right]$, where $t_{n}-t_{0}$ represent the number of years between two periods.
} 
Table 1: Descriptive statistics, means and (standard deviations) for the three sub-samples

\begin{tabular}{lccc}
\hline \multicolumn{1}{c}{ Variables } & Balanced-sample & \multicolumn{2}{c}{ Unbalanced-sample } \\
\hline & $\begin{array}{c}\text { Continuous R\&D } \\
\text { performers }\end{array}$ & $\begin{array}{c}\text { All R\&D } \\
\text { performers }\end{array}$ & $\begin{array}{c}\text { Large R\&D } \\
\text { performers }\end{array}$ \\
\hline Q/L & $169.8(133.5)$ & $162.42(151.9)$ & $219.4(182.0)$ \\
$\Delta(\mathrm{Q} / \mathrm{L})$ & $0.168(1.029)$ & $0.257(1.778)$ & $0.314(2.146)$ \\
Radical R\&D & $0.408(0.491)$ & $0.458(0.498)$ & $0.307(0.459)$ \\
\hline Exp_Strat_m/Q & $0.074(0.318)$ & $0.099(0.622)$ & $0.181(1.513)$ \\
Exp_Strat_mb/Q & $0.083(0.459)$ & $0.197(1.744)$ & $0.397(2.152)$ \\
Exp_Strat_mbs/Q & $0.021(0.330)$ & $0.037(1.135)$ & $0.163(1.663)$ \\
Exp_Strat_ms/Q & $0.010(0.136)$ & $0.012(0.257)$ & $0.057(0.617)$ \\
$\Delta$ L & $0.131(0.746)$ & $0.180(1.188)$ & $0.173(1.110)$ \\
$\Delta$ Absorptive & $0.226(1.312)$ & $0.223(1.369)$ & $0.365(2.156)$ \\
Absorptive & $0.266(0.278)$ & $0.288(0.314)$ & $0.344(0.310)$ \\
Domestic & $0.557(0.497)$ & $0.634(0.448)$ & $0.459(0.498)$ \\
Startup & $0.024(0.153)$ & $0.051(0.220)$ & $0.121(0.326)$ \\
High_tech & $0.077(0.267)$ & $0.030(0.172)$ & $0.115(0.319)$ \\
Medium_High_tech & $0.424(0.494)$ & $0.366(0.482)$ & $0.469(0.499)$ \\
Medium_Low_tech & $0.351(0.477)$ & $0.368(0.482)$ & $0.282(0.450)$ \\
Low_tech & $0.147(0.354)$ & $0.235(0.482)$ & $0.133(0.340)$ \\
\hline Strat_m & $0.450(0.497)$ & $0.473(0.499)$ & $0.327(0.469)$ \\
Strat_mb & $0.475(0.499)$ & $0.479(0.499)$ & $0.493(0.499)$ \\
Strat_mbs & $0.047(0.212)$ & $0.029(0.169)$ & $0.116(0.320)$ \\
Strat_ms & $0.028(0.163)$ & $0.019(0.132)$ & $0.064(0.245)$ \\
\hline Number of observations & 17,300 & 125,568 & 10.079 \\
\hline & & & \\
\hline
\end{tabular}

Source: Statistics Canada, RDCI Survey (calculation from the authors).

1980; Griliches, 1986)]. In this study we distinguish between radical and incremental R\&D (see appendix A1 for definitions). We define radical $R \& D$ (Radical $\mathbf{R} \& \mathbf{D}$ ) by a binary variable taking the value one if the firm performs $\mathrm{R} \& \mathrm{D}$ to develop new products, processes, technical services or to perform basic $\mathrm{R} \& \mathrm{D}$, as opposed to incremental $\mathrm{R} \& \mathrm{D}$, which includes applied research and improvement on existing products, processes or technical services. This measure can be viewed as a proxy for innovativeness. Radical R\&D leads to a new technological trajectory [Battaggion and Grieco (2007)]. Such a trajectory can lead to the creation of a new market or new product applications. The degree of innovativeness depends broadly on 
the nature of R\&D [Duguet (2006)]: the more a firm conducts radical R\&D, the higher is its likelihood to develop new products or processes and ultimately new markets. Generally, the literature reports higher returns for basic R\&D as opposed to applied or developed R\&D [(Link, 1990; Battaggion and Grieco, 2007)] to compensate for the initial risk and the duration of the investment. Finally, we include dummy variables representing four specific grouped industries characterized by their level of technology intensity following the OECD classification [Hatzichronoglou (1997)] (High_tech; Medium_High_tech; Medium_Low_tech and Low_tech). The details for these groups of industries are given in appendix (table A2).

Table 1 provides descriptive statistics on the variables used in the estimated models in each of the three sub-samples. We see that the largest part of the R\&D expenditure corresponds to R\&D strategies (Exp_Strat_m) and (Exp_Strat_mb). These percentages are higher for large R\&D performers than for all R\&D performers, and higher for all R\&D performers in the unbalanced sample than for the balanced sample of continuous R\&D performers. It should also be noted that there is much more variability in the $R \& D$ expenditure ratios for all and large $R \& D$ performers than for continuous $R \& D$ performers. At the bottom of the table we report the frequencies of strategy choices. Most firms choose to do make it alone (Strat_m) or then make and buy (Strat_mb). We can also see that larger firms pursue more often than the other firms strategies (Strat_mb) or (Strat_ms). This result is probably due to the nature of research. Usually, extramural $R \& D$ activities are more related with the learning and knowledge acquisition as compared to intramural R\&D activities, which are more oriented to the introduction of new products and process innovations [Beneito and Barrachina (2009)]. Large R\&D performers are basically under foreign control and do much less radical R\&D than continuous R\&D performers that are mostly under domestic control.

Tables 2 shows the relation between the firm size and the proportion of R\&D performed in a closed (as opposed to an open) mode for the three sub-samples. The R\&D performed in an open mode refers to $R \& D$ payments made or received by firms for $R \& D$ services (the make-buy, make-sell, and make-buysell strategies in our terminology of section 2.1). The R\&D performed in a closed mode refers to $R \& D$ expenditure made and financed in house (the "make" part in our terminology of section 2.1). Whatever the size or funding strategy of the firm, the percentage of firms that perform R\&D in an open mode is always slightly higher than the percentage of firms that perform R\&D in a closed mode.

The gap between the R\&D performed in the closed and open modes becomes greater for the subsample of large R\&D performers. However, for the full sample and the sub-sample of continuous R\&D performers, the size of the firm is not necessary correlated with the R\&D performed in a closed mode or in an open mode, the differences in percentages are too small. This argument is in line with Gambardella (1992) and Beneito (2003) who have argued that larger firms are less likely to outsource their R\&D because their scale advantage allows them to undertake R\&D intramurally, even though their larger 
technological absorptive capacity permits them to fully benefit from extramural R\&D.

Table 2: R\&D breakdown by size and executing/funding strategy for each sub-sample (in percentage of all performers of each sub-sample)

\begin{tabular}{l|ccc|ccc}
\hline \hline & \multicolumn{3}{|c}{ Strat_m } & \multicolumn{3}{c}{ Strat_mb+Strat_mbs+Strat_ms } \\
\hline Sub_sample & $(1-49)$ & $(50-499)$ & $(+500)$ & $(1-49)$ & $(50-499)$ & $(+500)$ \\
\hline Continuous R\&D performers & 30.4 & 12.6 & 2.0 & 31.9 & 17.9 & 5.2 \\
All R\&D performers & 37.0 & 9.3 & 1.0 & 38.7 & 11.8 & 2.2 \\
Large R\&D performers & 7.1 & 18.8 & 6.8 & 16.7 & 32.6 & 18.0 \\
\hline
\end{tabular}

Source: Statistics Canada, RDCI Survey (calculation from the authors).

Not surprising, the large R\&D performers behave differently. The large performers draw benefits from scale economies and are more concentrated in high and medium-high technology industries. The greater is the firm's size, the greater is its likelihood to perform R\&D in an open mode. In this sub-sample, $50.6 \%$ of firms with more than fifty employees perform R\&D in an open mode, compared to respectively $14.0 \%$ and $23.1 \%$ for the sub-samples of all and continuous R\&D performers. This result is in line with Cassiman and Veugelers (1999) who found that "small firms are more likely to restrict their innovation to an exclusive make or buy strategy".

\section{Econometric issues and specifications}

In this section we are interested in estimating the transitions between the four R\&D strategies (Strat_m; Strat_mb; Strat_mbs and Strat_ms) described in section 2.1. The transition probabilities express the likelihood of switching from a strategy in period t to a strategy in period $(\mathrm{t}+1)$.

\subsection{The dynamic multinomial Logit model with unobserved heterogeneity}

We analyze the dynamics in the choice of $R \& D$ strategies in the business sector using Canadian firm panel data. More specifically, we estimate a dynamic multinomial Logit model with unobserved heterogeneities correlated over alternatives [(Van Nguyen et al., 2004; Uhlendorff, 2006)]. The introduction of unobserved firm-specific effects allows to overcome the unrealistic limitation of no correlation between alternatives contained in the standard multinomial Logit model (i.e., it does not exhibit the independence from irrelevant alternatives (IIA) assumption). This model belongs to the class of mixed Logit models (see Train, 2003). The mixed Logit probabilities are the integrals of standard Logit probabilities over a density of parameters. The probability for a given firm $i$ to adopt strategy $j$ at time $t$ conditional on the observed characteristics $X_{i t}$, firm-specific unobserved heterogeneity $\alpha_{i j}$, and previous adopted R\&D strategy $Z_{i t-1}$ 
is:

$$
P\left(Z_{i j t} \mid X_{i t}, Z_{i t-1}, \alpha_{i}\right)=\int\left(\frac{\exp \left(\beta_{j} X_{i t}+\gamma_{j} Z_{i t-1}+\alpha_{i j}\right)}{\sum_{k=1}^{J} \exp \left(\beta_{k} X_{i t}+\gamma_{k} Z_{i t-1}+\alpha_{i k}\right)}\right) f\left(\alpha_{i}\right) d \alpha_{i}
$$

where $j \in J=\left(\right.$ Strat_m; Strat_mb; Strat_mbs; Strat_ms), and $\alpha_{i}$ is a four-variate random variable with multivariate density $f\left(\alpha_{i}\right)$.

The vector of explanatory variables $X_{i t}$ contains observable firm' specific characteristics in period (t), and $Z_{i t-1}$ is a vector of dummy variables indicating the $\mathrm{R} \& \mathrm{D}$ strategies adopted in period (t-1) with the make only strategy (Strat_m) as the base category. $\beta_{j}$ and $\gamma_{j}$ are vectors of fixed coefficients. The coefficients $\beta_{1}$ and $\gamma_{1}$ and the unobserved heterogeneity $\alpha_{i 1}$ specific to the base category are set to zero to allow for the identification of the model. The term $\alpha_{i j}$ is a random effect representing the specific unobserved heterogeneity across individual firms in choosing alternative $(\mathrm{j})$. This term does not very over time. In our model we have four alternatives, in consequence the vector of the specific unobserved heterogeneities is represented by $\alpha_{i}=\left\{\alpha_{i 1}, \alpha_{i 2}, \alpha_{i 3}, \alpha_{i 4}\right\}$. The term $\alpha_{i}$ is identically and independently distributed over individual firms and follows a multivariate normal distribution. The distribution of the unobserved heterogeneities allows for correlation over alternatives.

\subsection{Estimation by Maximum Simulated Likelihood (MSL)}

Our starting point is an empirical application of a STATA routine using maximum simulated likelihood (MSL) following a first-order Markov process. The detailed discussion on the advantage of this procedure compared to the Gauss-Hermite quadrature procedure is proposed in (Haan and Uhlendorff, 2006; Gong and Villagomez, 2000; Heckman, 1981). Our contribution to this empirical literature consists in modeling an extension of this procedure to a more complex choice model with four discrete alternatives. As mentioned in Haan and Uhlendorff (2006), the (MSL) leads to an equivalent estimate as the Gauss Hermite quadrature or adaptive quadrature to solve the integration issue. However, this simulation method is more time efficient than the adaptive quadrature approach. Considering the large number of observations in our RDCI full sample, the time required for the estimation becomes a sensitive issue.

Because the behavioral process of the firm's choice can not be calculated analytically, it will be estimated by approximation through maximum simulated likelihood (MSL). But, before performing the (MSL) we apply the STATA procedure (mdraws) proposed by Cappellari and Jenkins (2006) to generate Halton sequences. We create draws for each firm. The individual contribution is given by the simulated likelihood function (2) where the integral is replaced by the simulated likelihood expression (3). Thus the likelihood expression of the multinomial Logit with unobserved heterogeneity is for firm $i$ :

$$
L_{i}=\int_{-\infty}^{\infty} \prod_{t=1}^{T} \prod_{j=1}^{J}\left(\frac{\exp \left(\beta_{j} X_{i t}+\gamma_{j} Z_{i t-1}+\alpha_{i j}\right)}{\sum_{k=1}^{J} \exp \left(\beta_{k} X_{i t}+\gamma_{k} Z_{i t-1}+\alpha_{i k}\right)}\right)^{d_{i j t}} f\left(\alpha_{i}\right) d \alpha_{i}
$$


where $d_{i j t}=1$ is an index function equal to 1 if the alternative $j$ is chosen by firm $i$ at time $t$, and 0 otherwise. The number of draws $(R)$ by construction determines the variance of the unbiased estimated probability (P) which decreases as (R) increases [Revelt and Train (1998)]. The distribution of the unobserved heterogeneity with $(j=2,3,4)$ is drawn from a standard normal distribution and can be written as:

$$
\left(\begin{array}{c}
\alpha_{i 2} \\
\alpha_{i 3} \\
\alpha_{i 4}
\end{array}\right) \sim N\left(\left(\begin{array}{c}
0 \\
0 \\
0
\end{array}\right),\left(\begin{array}{ccc}
\sigma_{\alpha_{i 2}}^{2} & \sigma_{\alpha_{i 2} \alpha_{i 3}} & \sigma_{\alpha_{i 2} \alpha_{i 4}} \\
\sigma_{\alpha_{i 2} \alpha_{i 3}} & \sigma_{\alpha_{i 3}}^{2} & \sigma_{\alpha_{i 3} \alpha_{i 4}} \\
\sigma_{\alpha_{i 2} \alpha_{i 4}} & \sigma_{\alpha_{i 3} \alpha_{i 4}} & \sigma_{\alpha_{i 4}}^{2}
\end{array}\right)\right)
$$

This model is estimated with a Maximum Simulated Likelihood (MSL) because there exists no closed form solution for expression 2. Hence, equation 2 is simulated by:

$$
S L_{i}^{R}=\frac{1}{R} \sum_{r=1}^{R} \prod_{t=1}^{T} \prod_{j=1}^{J}\left(\frac{\exp \left(\beta_{j} X_{i t}+\gamma_{j} Z_{i t-1}+\alpha_{i j}^{r}\right)}{\sum_{k=1}^{J} \exp \left(\beta_{k} X_{i t}+\gamma_{k} Z_{i t-1}+\alpha_{i k}^{r}\right)}\right)^{d_{i j t}}
$$

The calculation of the unobserved random term effect $\alpha^{r}$ is done using a Cholesky factor $\mathrm{C}$ such as $\alpha^{r}=C \epsilon^{r}$ where $r$ denotes the $r^{t h}$ draw. Hence, the $r^{t h}$ draw of the distribution of $\alpha$ is calculated as:

$$
\begin{aligned}
& \alpha_{i 2}=c_{22} * \epsilon_{2} \\
& \alpha_{i 3}=c_{32} * \epsilon_{2}+c_{33} * \epsilon_{3} \\
& \alpha_{i 4}=c_{42} * \epsilon_{2}+c_{43} * \epsilon_{3}+c_{44} * \epsilon_{4}
\end{aligned}
$$

where $\epsilon_{2}, \epsilon_{3}, \epsilon_{4}$ follows a trivariate standard normal distribution.

The random terms $\alpha_{i 2}, \alpha_{i 3}$ and $\alpha_{i 4}$ are correlated because of the influence of $\epsilon_{2}$ on the three of them and of $\epsilon_{3}$ on the last two of them [Train (2003)]. The estimation results by maximum simulated likelihood of equation (3) gives a direct estimate of the elements of the Cholesky factor C. Then, we need to calculate the variance-covariance matrix $\mathrm{W}=\mathrm{CC}$ ' in order to extract the variance-covariance matrix of $\alpha_{i}$. Also, to calculate the standard errors and the confidence intervals for each element of matrix $\mathrm{W}$ we apply the delta method $^{4}$, an asymptotic normal approximation method.

\footnotetext{
${ }^{4}$ We used the STATA command _diparm where we have to specify the function of the parameters in the matrix $\mathrm{W}$ and its partial derivatives. This command is a programmer's utility for displaying ancillary parameters. This is useful to reverse the transformation post-estimation and derive the variance-covariance matrix of the relevant parameters of original metric Jenkins (2003).
} 


\section{Results of the dynamic multinomial Logit model with indi- vidual heterogeneity}

Table 3 reports the observed transitions between the four R\&D strategies during the period 1997 to 2006 for the sub-sample of continuous R\&D performers. The proportion of firms that stick to the same strategy over two successive periods is highest for the firms that opted for the strategy make (with $36 \%$ ) and make-buy (with 38\%). One also observes that a non-negligible portion of performers (8\%) switch from (Strat_m) to (Strat_mb) and vice-versa, in other words, they switch from a strategy where they do intramural R\&D exclusively to a strategy where they also have some R\&D done extramurally. But only $1 \%$ of the firms switch from (Strat_mb) to (Strat_mbs) and vice-versa. Table 3 also shows that firms tend to stick to the same strategy over time whatever their initial strategy. The proportion of firms that switch from (Strat_m) to (Strat_mb) and vice versa is higher than any other switching of strategies. The observed transitions suggest there is strong true state dependence. The choice of a given R\&D strategy in one period is likely to be followed by the choice of that same strategy in the next period. It is also noticeable that the observed transition matrix is not far from being symmetric.

Table 3: Observed transition matrix for continuous R\&D performers (balanced panel, in \%)

\begin{tabular}{l|cccc|c}
\hline \hline & \multicolumn{5}{|c}{} \\
& Strat_m $(t)$ & Strat_mb(t) & Strat_mbs(t) & Strat_ms $(t)$ & Total \\
\hline Strat_m(t-1) & 36.2 & 7.9 & 0.3 & 0.6 & 45.1 \\
Strat_mb(t-1) & 7.9 & 38.0 & 1.1 & 0.2 & 47.2 \\
Strat_mbs(t-1) & 0.3 & 1.4 & 2.9 & 0.3 & 4.9 \\
Strat_ms(t-1) & 0.8 & 0.3 & 0.3 & 1.4 & 2.8 \\
\hline Total & 45.2 & 47.6 & 4.6 & 2.6 & 100 \\
\hline
\end{tabular}

Source: Statistics Canada, RDCI Survey (calculation from the author).

The results of the estimated dynamic multinomial Logit model with unobserved heterogeneity are reported in table 4 and their marginal effects ${ }^{5}$ in table 5 . Each column of parameters in table 4 corresponds to the expression of the logarithm of the log-odds ratio of strategy $\mathrm{j}$, where $\mathrm{j}=$ (Strat_mb, Strat_mbs, Strat_ms), compared to the reference strategy (Strat_m). The model has been estimated only on the balanced panel i.e. for the sub-sample of continuous R\&D performers. We also present separate estimates for the sub-samples of foreign and domestic continuous R\&D performers ${ }^{6}$.

We control for the annual employment growth $\Delta(\mathrm{L})$, which captures a scale effect, the annual absorptive capacity growth $\Delta$ (Absorptive), a dummy for startups (Startup), technological differentiation 
(High_tech; Medium_High_tech; Medium_Low_tech and Low_tech) and year-dummies for the period 1997 to 2006. The comparison of the estimates in table 4 and those of the multinomial Logit without individualfirm effects (table A3) ${ }^{7}$ shows that the inclusion of unobserved heterogeneity in the model improves significantly the log-likelihood and reduces the magnitude of the transition coefficients. The elements of the variance-covariance matrix are for the most part significantly different from zero, indicating that the strategy choices are not mutually independent. The three ways of conducting R\&D in an open mode are positively correlated with each other through their individual effects. Any unobserved influence that increases the odds of pursuing one of the three open R\&D strategies will also increase the odds of pursuing any of the other two. Comparing the sum of the two log-likelihoods for the continuous domestic and foreign controlled R\&D performers to the log-likelihood on the sub-sample of all continuous R\&D performers provides a likelihood ratio test of the homogeneity across ownership. The chi-square statistic is 63.786 , which exceeds the tabulated value for a chi-square with 36 degrees of freedom at the $5 \%$ level of significance. The model has different parameter values for domestic and foreign-owned firms. Also, we tested the two models, respectively with and without unobserved heterogeneities in order to see whether the model with heterogeneity is preferred. We performed a Likelihood Ratio test (LR) on the three sub-samples. The LR test statistics were respectively (323.95; 153.04 and 180.22). The table value for this test with 6 degree of freedom from the chi-squared table is (12.59). Since the computed values are larger than this critical value at the 0.005 level, the null hypothesis Ho: $\left(\sigma_{\alpha_{i 2}}^{2}=0 ; \sigma_{\alpha_{i 3}}^{2}=0 ; \sigma_{\alpha_{i 4}}^{2}=0\right.$; $\sigma_{\alpha_{i 2} \alpha_{i 3}}=0 ; \sigma_{\alpha_{i 2} \alpha_{i 4}}=0$ and $\left.\sigma_{\alpha_{i 3} \alpha_{i 4}}=0\right)$ is rejected for all the sub-samples, suggesting that the model with heterogeneity is preferred.

The results displayed in table 5 show that there is a high persistence in the way R\&D is done for all three sub-samples ${ }^{8}$. A continuous R\&D performer who adopts strategy make and buy (Strat_mb) in period ( $\mathrm{t}-1$ ) instead of strategy (Strat_m), the reference strategy, has a $50 \%$ chance to stick to that strategy in the next period instead of switching to strategy make only (Strat_m). This persistence is evaluated at $34 \%$ for (Strat_mbs) and $20 \%$ for (Strat_ms). What about (Strat_m)? Well, since it is

\footnotetext{
${ }^{5}$ The marginal effects indicate the percentage marginal change in the probability of choosing a given strategy of R\&D due to a unit change in the explanatory variable. The calculation of the marginal change in predicted probabilities $\left(P_{i}\right)$ is for continuous explanatory variables given by $\frac{\partial P_{i}}{\partial x_{i}}=P_{i}\left[\beta_{i}-\sum_{k=0}^{J} P_{k} \beta_{k}\right]$, and for dummy variables by $\Delta P_{i}=P_{i}(1)-P_{i}(0)$, i.e. the difference in the predicted probabilities for values 1 and 0 of the dummy variables. We apply the same definitions for the parameters $\gamma_{i}$ from the equation (2.)

${ }^{6}$ Given that we only observe whether enterprises leave the sample, but do not know anything about the causes for exiting, we consider that we do not have any information to properly address any issue related to panel attrition in this study [Van Nguyen et al. (2004)]. The problem of attrition does not occur as long as the unobserved individual heterogeneities that influence the dynamics of $R \& D$ are not correlated with the unobserved factors that influence the attrition process, see Uhlendorff (2006).

${ }^{7}$ The multinomial Logit without individual heterogeneity reported in table A3 of the appendix provides us the initial parameters for implementing the multinomial Logit model with individual heterogeneity.
} 


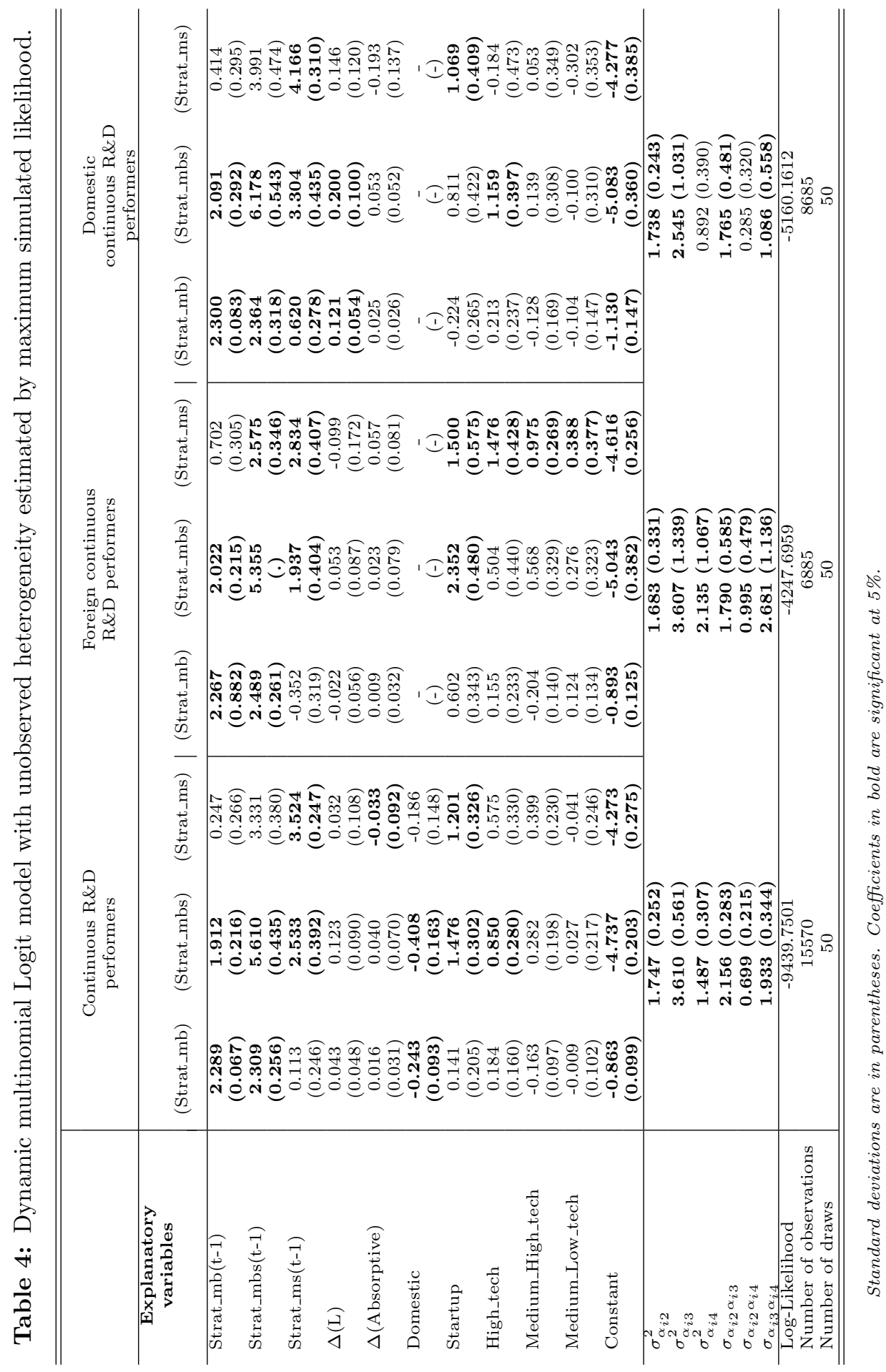




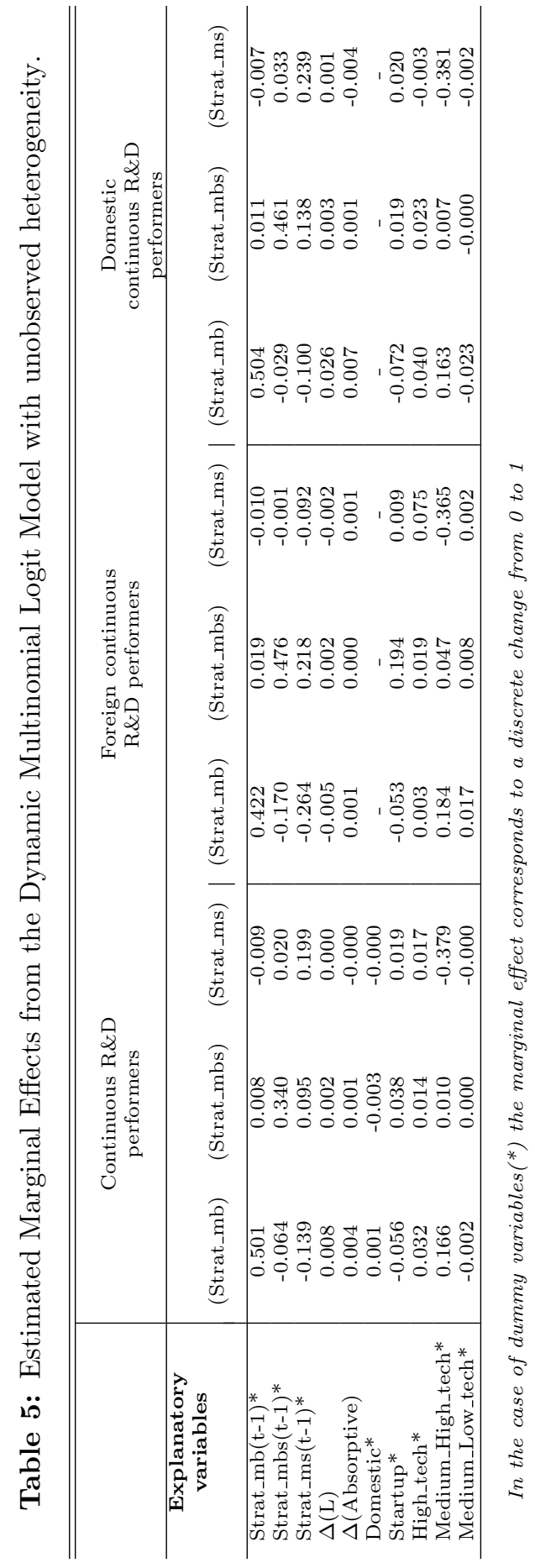


the reference strategy, we can compute the odds-ratio of following strategies (Strat_mb), (Strat_mbs) and (Strat_ms) compared to (Strat_m) in (t), if (Strat_m) is adopted in (t-1). These are obtained by exponentiating the constants of table 4 for firms in low-tech sectors, without growth of employment and absorptive capacity,that are foreign-controlled and startup firms. For continuous R\&D performers we get respectively 0.422, 0.009 and 0.014 . The odds are clearly in favor of sticking to (Strat_m). Hence, besides the evidence of persistence of innovation found in the literature (see Antonelli et al, 2013 and the table 1 therein surveying the literature), we also find persistence in the way of doing $R \& D$, in other words path dependence as also found in Antonelli et al (2013).

Table 5 also reveals how much firms switch among strategies. The most important switches happen after a firm has followed the make and sell strategy. Doing (Strat_ms) in period (t-1) increases by almost $10 \%$ the odds of doing (Strat_mbs) in period ( $\mathrm{t}$ ) and decreases by $14 \%$ the odds of doing (Strat_mb) in period (t) compared to doing (Strat_m). Once a firm does R\&D for itself and for others, it turns towards more external $R \& D$ in place of internal $R \& D$, but combined with selling $R \& D$. We can consider this evolution of R\&D behavior as an increased specialization with internal and external knowledge sourcing and transfer of R\&D services to outsiders. The trajectory of organizational learning in the way of performing R\&D that was hypothesized in Section 2.2 seems to be validated. Firms that start with make and buy tend to move to (strat_mbs), those that were at (strat_mbs) do not go back to (strat_mb) but might specialize further into (strat_ms), and those that were at (strat_ms) tend to move to (strat_mbs). But most firms tend to stick with their original strategy. Foreign controlled firms would have a $22 \%$ higher probability to follow up the next period with a (Strat_mbs) strategy and a $26 \%$ lower probability to go for a strategy (Strat_mb). In contrast, domestic firms would have only a $14 \%$ higher chance to follow up with the strategy (Strat_mbs), and a 10\% lower probability to make and buy R\&D (Strat_mb), always of course compared to adopting an exclusive strategy (Strat_m). This result confirms our expectation that foreign controlled firms have a higher probability to specialize in their R\&D operations than Canadian controlled firms.

There is also an industry effect in the way $R \& D$ is conducted and financed. The strategy make-andbuy is more frequent and the strategy make-and-sell less frequent in medium-high-tech industries than in low-tech industries, whatever the firm's country of control. The effects of the other variables can be summarized as follows. Firms in high-tech industries in (t-1) have a higher probability of choosing the R\&D strategy make-buy-sell (Strat_mbs) in the next period. Startups have a tendency of doing less make and buy and more make and sell or even make, buy and sell compared to make only, especially in foreign

\footnotetext{
${ }^{8}$ The persistence effect that we estimate is probably somewhat upward biased because we have treated the initial condition as exogenous. We have chosen to do so, because the data prior to 1996 were of a different quality than those from 1997 onwards and because conditioning on the observed value of 1997, as Wooldridge (2005) simple solution would recommend, would reduce too much the size of our sample especially for the sub-sample of foreign continuous R\&D performers.
} 
controlled firms. Startups firms have a 19\% higher probability of choosing the strategy (Strat_mbs) in firms under foreign control as compared to $2 \%$ for domestic continuous R\&D performers.

Table 6 shows the estimated transition matrix of $R \& D$ strategies based on the predicted average transition probabilities calculated from the dynamic multinomial Logit model with unobserved heterogeneity (table 4) using the representative firm's characteristics. This approach is similar to the one suggested by Gong and Villagomez (2000). Predicted probabilities are useful to validate whether the model reproduces the data. The predicted transition probabilities are quite close to the observed transitions shown in table 4. R\&D performers tend to reproduce their past strategies. $R \& D$ performers with an open strategy have a higher likelihood of pursuing the open strategy compared to those who initially opted for an exclusively intramural strategy (Strat_m). The estimated matrix of transitions (table 6) shows that the proportion of enterprises that have moved from a closed mode to an open mode is approximatively the same as the proportion of those that switched from an open mode to a closed mode $(12 \%)$.

Table 6: Predicted transition matrix for continuous R\&D performers (balanced panel, in \%)

\begin{tabular}{l|cccc|c}
\hline \hline & Strat_m(t) & Strat_mb $(t)$ & Strat_mbs $(t)$ & Strat_ms $(t)$ & Total \\
\hline Strat_m(t-1) & $32.8(1.45)$ & $11.4(1.36)$ & $0.3(0.17)$ & $0.5(0.21)$ & 45.0 \\
Strat_mb(t-1) & $10.3(1.33)$ & $36.1(1.31)$ & $0.6(0.36)$ & $0.2(0.09)$ & 47.2 \\
Strat_mbs(t-1) & $0.6(0.14)$ & $2.2(0.38)$ & $1.8(0.46)$ & $0.3(0.06)$ & 4.9 \\
Strat_ms(t-1) & $1.3(0.18)$ & $0.5(0.08)$ & $0.2(0.06)$ & $0.8(0.17)$ & 2.8 \\
\hline Total & 45.0 & 50.2 & 3.0 & 1.8 & 100 \\
\hline
\end{tabular}

Values in parentheses are the standard errors

The state dependence describes the effect of favoring one strategy in one period on the probability of keeping at strategy in the following period. This difference in estimated probabilities is much more informative that the simple observation of the effects from the estimates of the dynamic multinomial. For instance, following Uhlendorff (2006), the state dependence of strategy (Strat_mb) is given by the difference in the probability of pursuing that strategy in two successive periods and the probability of moving from (Strat_m) towards (Strat_mb).

$$
S D(m b)=\frac{1}{N} \sum_{i=1}^{N}\left(P_{i}\left(j_{t}=m b \mid j_{t-1}=m b\right)-P_{i}\left(j_{t}=m b \mid j_{t-1}=m\right)\right) .
$$

This method is more in line with the idea of the trajectory of organizational learning [Levitt and March (1988)] in the way of doing R\&D insofar as we compare the difference in the probability of choosing a given strategy depending on whether the initial strategy was the same one or not. During their lifetime, firms learn from their past experience and from the experience acquired by other R\&D performers. 
Table 7: Estimated State Dependence (SD) with respect to reference departure state (Strat_m))

\begin{tabular}{lccc}
\hline \hline & Variables & Balanced-panel & \\
& All continuous R\&D & Foreign continuous \\
performers & R\&D performers & $\begin{array}{c}\text { Domestic continuous } \\
\text { R\&D performers }\end{array}$ & \\
\hline $\mathrm{SD}(\mathrm{mb})$ & $0.323(0.342)$ & $0.302(0.330)$ & $0.345(0.350)$ \\
$\mathrm{SD}(\mathrm{mbs})$ & $0.176^{* * *}(0.080)$ & $0.209^{* * *}(0.098)$ & $0.016(0.073)$ \\
$\mathrm{SD}(\mathrm{ms})$ & $0.007(0.047)$ & $0.009(0.057)$ & $0.006(0.039)$ \\
\hline
\end{tabular}

note: Standard deviations are in parentheses. *** $\mathrm{p} \prec 0.01 ; * * \mathrm{p} \prec 0.05 ;{ }^{*} \mathrm{p} \prec 0.1$

The learning mechanism of $R \& D$ is embedded in the organizational memory of the enterprise. The enterprise experiments with different $R \& D$ strategies and adopts the one that maximizes its technological performance. However, any change in the way of acquiring R\&D may result in considerable risk-taking and may alter the organizational memory of the enterprise in its R\&D expertise (know-how). In sum, the technological trajectory of the firm depends on its history of successes or failures in performing R\&D in a closed or open mode ${ }^{9}$.

The results of table 7 indicate that the probability of adopting a given open mode strategy is higher if the firm was initially following that open mode strategy as opposed to the closed mode strategy. All state dependences are positive indicating that persistence of open mode strategies outweigh transitions from closed mode to open mode strategies, although the differences are significant only for strategy (Start_mbs). In the sub-sample of foreign continuous R\&D performers, the state dependence effect is especially high, and significantly so, for (Strat_mbs) with a $21 \%$ higher probability of sticking to (Strat_mbs) than of switching from (Strat_m) to (Strat_mbs). An interesting question is whether these strategy choices have any impact on firms' performance. This is what we propose to do in the next section.

\section{$6 \quad$ R\&D organization and firm performance}

It is generally accepted that $R \& D$ contributes to economic growth and welfare by reducing the production costs and by widening the variety and the quantity of goods available. A huge empirical literature has been devoted to estimating the returns to R\&D (see Hall et al., 2010). The way in which R\&D is generated and acquired may also affect economic performance. Very little empirical research examined the role of

\footnotetext{
${ }^{9}$ For example, to calculate the predicted conditional probability $P_{i}\left(j_{t}=m b \mid j_{t-1}=m b\right)$, we set the R\&D strategy $(\text { Strat_mb })_{t-1}$ to 1 and the other lagged strategies to 0 in the expression of the multinomial Logit model from table 4 . For the calculation of $P_{i}\left(j_{t}=m b \mid j_{t-1}=m\right)$, we do the same: the R\&D strategy (Strat_m $)_{t-1}$ is set to 1 and the other lagged strategies to 0 . Finally, to calculate the state dependence, we subtract these two predicted probabilities.
} 
the way of doing R\&D on firms' performance [see D'Aveni and Ravenscraft (1994), Kurokawa (1997), Veugelers (1997), Leiblein and Dalsace (2002), Rosa and Mohnen (2006), and Lokshin and Carree (2008)]. On the one hand, R\&D outsourcing reduces the risk and allows to benefit from synergies. On the other hand, R\&D internalization reduces transaction costs and coordination problems that are likely to occur with outside technology acquisition, and enhances the performance of firms due to lower administration and coordination problems associated with it. Moreover technological independence may be preferred in order to protect the intellectual property and minimize the problems related with external technological appropriation [(Teece, 1984, 1993, 1996)]. In the following section we seek to evaluate the returns from $R \& D$ depending on the internal/external organization of $R \& D$ activities. In our evaluation we take into account the existence of possible firm specific unobserved characteristics.

\subsection{Framework}

We start from an extended Cobb-Douglas production function, where output is produced with the traditional inputs, capital and labor, and the $\mathrm{R} \& \mathrm{D}$ stock of knowledge. If we ignore the $\mathrm{R} \& \mathrm{D}$ depreciation rate, we can rewrite the production function in growth rate form as:

$$
\Delta \ln \left(\frac{Q}{L}\right)_{i t}=\beta_{0 j}+\left(\beta_{1}-1\right) \Delta \ln (L)_{i t}+\sum_{j=1}^{4} \gamma_{j}\left(\text { Exp_Strat }_{-(j)} / Q\right)_{i t-1}+\beta_{2}(\text { Year })+\beta_{3}(\text { Industry })+\nu_{i t}
$$

where $\mathrm{Q}$ is output, $\mathrm{L}$ is labor, Exp_Strat ${ }_{j} / Q$ is the $\mathrm{R} \& \mathrm{D}$ expenditure in proportion to total revenue associated with strategy $\mathrm{j}(\mathrm{j}=\mathrm{m}, \mathrm{mb}, \mathrm{mbs}, \mathrm{ms}), \beta_{0}$ is the rate of disembodied technical change, $\beta_{1}$ is the output elasticity of labor, $\gamma_{j}$ are the rates of return to R\&D organized following strategy $\mathrm{j}, \beta_{2}$ captures the business cycle or technical change effect, $\beta_{3}$ an industry-specific effect and $\nu_{i t}$ is the idiosyncratic error term.

A few remarks are in order. First, since we do not have firm-specific data on the physical capital stock, we can only approximate its contribution via the industry-specific effect. Second, nominal output has been deflated by the industrial product price index 1997-2006. Measurement errors in output prices and incorrect $\mathrm{R} \& \mathrm{D}$ deflators are attenuated by the use of year and industry dummies. Third, $\gamma_{j}$ measures the gross rate of return. To arrive at the net rate of return a depreciation rate of say $15 \%$ ought to be subtracted from it. Moreover, depending on the magnitude of the depreciation rate and the growth rate of the R\&D stock, the gross rate of return could be underestimated by a factor of 2.5 to 5 using the gross investment instead of the net investment to output ratio (see Hall et al., 2010). Fourth, because it is unlikely that the present investment in $\mathrm{R} \& \mathrm{D}$ becomes productive immediately, it seems reasonable to expect a delay between the $R \& D$ investment and its return. The use of panel data allows us to introduce lags. According to the studies of Pakes and Griliches (1984) and Griffith et al. (2004) the lag effect drops sharply after two years. We lag the R\&D intensity by one period ${ }^{10}$. Fifth, we have included dummies 
to control for industry group effects according to their level of technology (see Table A2), following a classification similar to the one proposed in Hatzichronoglou (1997) and Loschky (2008).

\subsection{Rates of return to $R \& D$ depending on the way of doing $R \& D$}

The estimates of equation (4) are reported in table 8 for the three sub-samples of data. The usable sub-samples for this analysis have been reduced respectively to 15570, 89876 and 8504 observations representing 1730, 26109 and 2222 firms.

The findings suggest a systematic positive and highly significant rate of return of $R \& D$ for the three sub-samples, whatever the chosen $R \& D$ strategy. If we abstract from the exceptionally high rate of return of $92 \%$ corresponding to the strategy make-and-sell, the rates of return range between $12 \%$ and $57 \%$. The estimates of those returns are in line with similar studies for Canadian data [Hanel (1988), Bernstein (1989), Mohnen and Lépine (1991)]. In many cases, the differences between rates of return under different scenarios are not significantly different from each other. Nevertheless, we can notice the following regularities.

First, regarding differences in return due to the choice of $R \& D$ mode, we confirm the result of the study by Lokshin and Carree (2008) that the combination of internal and external R\&D leads to higher returns than the adoption of a single $R \& D$ strategy. For all $R \& D$ performers and for the large $R \& D$ performers we obtain higher rates of return for $R \& D$ conducted under the strategy (Strat_mb) than for R\&D conducted under the strategy (Strat_m). For continuous R\&D performers, mostly domestic firms, this is, however, not the case. There, it is the strategy (Strat_ms) that yields the highest rate of return. In all cases, pursuing an open R\&D strategy is more effective than adopting a closed R\&D strategy. However, the strategy (Strat_mbs) yields systematically the lowest rate of return. Second, it is remarkable to notice that continuous $R \& D$ performers obtain higher rates of return than occasional $R \& D$ performers for whatever R\&D strategy. Continuous $R \& D$ performers are more likely than occasional R\&D performers to reap benefits and to learn from sustained projects. Moreover, the portion of firms in high-tech industries is also relatively high in the sub-sample of continuous R\&D performers. Finally, the estimated rates of return earned on radical R\&D are always higher than those on total R\&D, confirming the results of Mansfield (1980), Link (1981) and Griliches (1986) on US data.

\section{Conclusion}

This paper has examined the determinants and the effects of strategic choices in the way of doing R\&D. We have expanded the scope of organizational choices beyond the traditional make and buy to distinguish

\footnotetext{
${ }^{10}$ We tried our specification with various lags and without lag for R\&D intensity ratio, and the most significant impacts for R\&D occurred with a one year lag as also suggested in Lokshin and Carree (2008).
} 
Table 8: The rate of return on R\&D by way of doing R\&D and by sub-samples

\begin{tabular}{|c|c|c|c|}
\hline \multirow[t]{3}{*}{ R\&D strategies } & \multirow{3}{*}{\begin{tabular}{c}
\multicolumn{2}{c}{ Balanced-panel } \\
Continuous R\&D performers \\
return $\quad$ (se)
\end{tabular}} & \multicolumn{2}{|c|}{ Unbalanced-panel } \\
\hline & & All R\&D performers & Large R\&D performers \\
\hline & & return & return \\
\hline \multicolumn{4}{|c|}{ Total R\&D } \\
\hline Exp_Strat_m/Q $\quad\left(\gamma_{1}\right)$ & $0.567^{* * *}(0.031)$ & $0.396^{* * *}(0.012)$ & $0.117^{* * *}(0.019)$ \\
\hline Exp_Strat_mb/Q $\quad\left(\gamma_{2}\right)$ & $0.422^{* * *}(0.025)$ & $0.412^{* * *}(0.008)$ & $0.257^{* * *}(0.015)$ \\
\hline Exp_Strat_mbs/Q $\quad\left(\gamma_{3}\right)$ & $0.378^{* * *}(0.029)$ & $0.209 * * *(0.012)$ & $0.149 * * *(0.017)$ \\
\hline Exp_Strat_ms/Q $\quad\left(\gamma_{4}\right)$ & $0.917^{* * *}(0.066)$ & $0.333^{* * *}(0.028)$ & $0.208^{* * *}(0.048)$ \\
\hline Number of observations & 15,570 & 89,876 & 8,504 \\
\hline R_square & 0.113 & 0.069 & 0.061 \\
\hline \multicolumn{4}{|c|}{ Radical R\&D } \\
\hline Exp_Strat_m/Q $\quad\left(\gamma_{1}\right)$ & $0.657^{* * *}(0.043)$ & $0.565 * * *(0.027)$ & $0.317^{* * *}(0.057)$ \\
\hline Exp_Strat_mb/Q $\quad\left(\gamma_{2}\right)$ & $0.677^{* * *}(0.053)$ & $0.651^{* * *}(0.016)$ & $0.258^{* * *}(0.036)$ \\
\hline Exp_Strat_mbs/Q $\quad\left(\gamma_{3}\right)$ & $0.547^{* * *}(0.104)$ & $0.247^{* * *}(0.027)$ & $0.092^{* * *}(0.045)$ \\
\hline Exp_Strat_ms/Q & $0.789^{* * *}(0.237)$ & $0.548^{* * *}(0.053)$ & $0.499^{* * *}(0.111)$ \\
\hline Number of observations & 6,307 & 38,982 & 2,450 \\
\hline R_square & 0.163 & 0.092 & 0.076 \\
\hline
\end{tabular}

Source: Statistics Canada, RDCI Survey

Note: Standard deviations are in parentheses. *** $\mathrm{p} \prec 0.01 ;{ }^{* *} \mathrm{p} \prec 0.05 ; * \mathrm{p} \prec 0.1$

The regressions also control for $\Delta \mathrm{L}$, year dummies and industry dummies.

four options. Firms can either operate in a closed mode and carry out R\&D for their own purpose (the make decision). They can also operate in a more open mode either by combining make and buy (i.e. have some of the R\&D done internally and some externally), or by combining make and sell (i.e. do $\mathrm{R} \& \mathrm{D}$ for themselves but also for others) or combine all three activities (make, buy and sell). Using an exceptionally large panel data set, namely the Research and Development in Canadian industry Survey conducted by Statistics Canada from 1997 to 2006, we have first estimated the determinants of the four choices of doing $\mathrm{R} \& \mathrm{D}$, allowing for dynamics and individual heterogeneity. Then we have estimated the rate of return on $R \& D$ in Canadian firms for various ways of doing $R \& D$.

Our analysis has shown that there is a high level of persistence in the way of doing R\&D at the firm-level (strong true state dependence), in particular for continuous R\&D performers. Thus, opting for a given strategy in the first period increases significantly the probability of keeping that same strategy in the next period. The state dependence is especially high for firms that operate in the make-buy-sell mode. Thus we can conclude that past experience in $R \& D$ is an important driver in the way that firms do their R\&D.

The returns to $R \& D$ are significantly higher for firms that are continuous $R \& D$ performers and for 
firms that do radical $R \& D$, by which we mean $R \& D$ that leads to new products, processes or technical services, as well as basic R\&D.

Our analysis has some methodological limitations. We have few control variables to explain productivity growth. In particular, we do not control for the stock of physical capital. The practical implementation of the Maximum Simulated Likelihood (MSL) raised many technical estimation issues for the non-balanced sub-samples. It would in particular be interesting to treat the presence of attrition (if the firm does not perform R\&D during some years). Finally, the availability of different instrumental variables for each $\mathrm{R} \& \mathrm{D}$ decision would have allowed us to estimate the production function considering each strategy as endogenous. The probabilities that we estimated in the multinomial Logit model are conditional on a first-order Markov process. To get a more realistic picture of the transition process, it might have been preferable to estimate the process with the dependent variable lagged by two or three periods. However, such a calculation is numerically very demanding in terms of estimation time and complexity. In our approach, we simplified the dynamic aspect of the estimation by relying on only one period lag. This restricts, however, our capability of describing the entire learning mechanism. 


\section{References}

Antonelli, C.; Crespi, F.; and Scellato, G. (2013). "Internal and External Factors in Innovation Persistence". Economic of Innovation and New Technology, 22(3), pp. 256-280.

Arora, A. and Gambardella, A. (1990). "Complementarity and External Linkages: The Strategies of the Large Firms in Biotechnology". The Journal of Industrial Economics Innovation and New Technology, 38(4), pp. 361-379.

Arrow, K. (1962). The Rate and Direction of Inventive Activity: Economic and Social Factors, chapter Economic Welfare and the Allocation of Resources for Invention, pages 609-626. National Bureau of Economic Research, Inc.

Battaggion, M. R. and Grieco, D. (2007). "R\&D Competition with Radical and Incremental Innovation". Technical report, CESPRI Bocconi University.

Baziliauskas, A. ; Horstmann, I. and Mathewson, F. (2007). "An Issues Paper on the Organization of Firms and Industrial Performance in Canada". Technical report, Industry Canada.

Belderbos, R. ; Carree, M. and Lokshin, B. (2006). "Complementarity in R\&D Cooperation Strategies". Review of Industrial Organization, 28(4), pp. 401-426.

Beneito, P. ; Sanchis-Llopis, A. S. and Barrachina, M. (2009). "The Role of Learning In Innovation In-House versus Extramurally Contracted R\&D Experience". Working papers 2009-11, Instituto Valenciano de Investigaciones Econmicas.

Beneito, P. (2003). "Choosing Among Alternative Technological Strategies: An Empirical Analysis of Formal Source of Innovation". Research policy, 32(4), pp. 693-713.

Bernstein, J. I. (1989). "The Structure of Canadian Inter-industry R\&D Spillovers and the Rates of Return to R\&D". Journal of Industrial Economics, 37(3), pp. 315-328.

Breschi, S.; Malarba, F. and Orsenigo, L. (2000). "Technological Regimes and Schumpeterien Patterns of Innovation". The Economic Journal, 110(463), pp. 388-410.

Cappellari, 1. and Jenkins, S. (2006). "Calculation of Multivariate Normal Probabilities by Simulation, with Applications to Maximum Simulated Likelihood Estimation". Discussion Papers 584, DIW Berlin, German Institute for Economic Research.

Cassiman, B. and Veugelers, R. (1999). "Make and Buy in Innovation Strategies: Evidence from Belgian Manufacturing Firms.". Research Policy, 28(1), pp. 63-80. 
Cassiman, B. ; Perez-Castrillo, D. and Veugelers, R. (2002). "Endogenizing Know-how Flows Through the Nature of R\&D Investments". International Journal of Industrial Organization, 20(6), pp. 775-799.

Cesaroni, F. (2004). "Technological Outsourcing and Product Diversification: Do Markets for Technology Affect Firms' Strategies?". Research Policy, 33(10), pp. 1547-1564.

Chesbrough, H. W.; Vanhaverbeke, W.; and West, W. (2006). Open Innovation: Researching a New Paradigm. Oxford University Press.

Cohen, W. M. and Levinthal, D. A. (1990). "Absorptive Capacity: A New Perspective on Learning and Innovation". Administrative Science Quarterly, 35(1), pp. 128-152.

D'Aveni, R. A. and Ravenscraft, D. J. (1994). "Economies of Integration Versus Bureaucracy Cost: Does Vertcal Integration Improve Performance?". Academy of Management Journal, 37(5), pp. 1167-1206.

Delacroix, J. and Swaminathan, A. (1991). "Cosmetic, Speculative, and Adaptative Organizational Change in the Wine Industry: A Longitudinal Study". Administrative Science Quarterly, 36(4), pp. 631-661.

Drechsler, W. and Natter, M. (2012). "Understanding a Firm's Openness Decisions in Innovation". Journal of Business Research, 65(3), pp. 438-445.

Duguet, E. (2006). "Innovation Height, Spillovers and TPF Growth at the Firm Level: Evidence from French Manufacturing". Economics of Innovation and New Technology, 15(4-5), pp. 415-442.

Fernandez-Bagues, M. (2003). "Complementarity in Innovation Strategies: Evidence from Pharmaceutical Dynamic Panel Data.". Paper presented at the 30th EARIE conference in Helsinki.

Fors, G. (1997). "Utilization of R\&D Results in the Home and Foreign Plants of Multinationals". The Journal of Industrial Economics Innovation and New Technology, 45(2), pp. 341-358.

Gambardella, A. (1992). "Competitive Advantages from In-house Scientific Research: Th US. Pharmaceutical Industry in the 1980s.". Research Policy, 21(5), pp. 391-407.

Garriga, H.; von Krogh, G.; and Spaeth, S. (2013). "How Constraints and Knowledge Impact Open Innovation". Strategic Management Journal, doi: 10.1002/smj.2049.

Gong, X .; Soest, A. V. and Villagomez, E. (2000). "Mobility in the Urban Labor Market : A Panel Data Analysis for Mexico". Discussion Paper 46, Tilburg University, Center for Economic Research.

Griffith, R.; Redding, S.; and Reenen, J. V. (2004). "Mapping the Two Faces of R\&D: Productivity Growth in a Panel of OECD Industries". The Review of Economics and Statistics, 86(4), pp. 883-895. 
Griliches, Z. (1986). "Productivity, R\&D, and Basic Research At the Firm Level in the 1970's". American Economic Review, 76(1), pp. 141-154.

Haan, P. and Uhlendorff, A. (2006). "Estimation of Multinomial Logit Models with Unobserved Heterogeneity Using Maximum Simulated Likelihood". The Stata Journal, 6(2), pp. 229-245.

Hall, B. H.; Mairesse, J.; and Mohnen, P. (2010). The Handbook of the Economics of Innovation, volume 2, chapter Measuring the Returns to R\&D, pages 1034-1082. Elsevier, 1 edition.

Hanel, P. (1988). "L'effet des dépenses en R-D sur la productivité du travail au Québec". Actualité Economique, 64(3), pp. 396-415.

Hanel, P. (2000). "R\&D, Interindustry and International Technology Spillovers and the Total Factor Productivity Growth of Manufacturing Industries in Canada, 1974-1989”. Economic Systems Research, 12(3), pp. 345-361.

Hatzichronoglou, T. (1997). "Revision of the High-Technology Sector and Product Classification". Science, Technology and Industry Working Papers. 1997/2., OECD.

Heckman, J. (1981). Structural Analysis of Discrete Data with Econometric Applications, chapter Statistical Models for Discrete Panel Data, pages 114-175. The MIT Press.

Jenkins, S, P. (2003). "Review of Maximum Likelihood Estimation with Stata by Gould, Piblado, and Sribney". The Stata Journal, 3(4), pp. 440-444.

Katsoulacos, Y. and Ulph, D. (1998). "Endogenous Spillovers and The Performance of Research Joint Venture.". Journal of industrial Economics, 46(3), pp. 333-357.

Kurokawa, S. (1997). "Make-or-Buy Decisions in R\&D Small Technology Based Firms in the UnitedStates and Japan". Transactions on Engineering Management, 44(2), pp. 124-134.

Leiblein, M. J.; Reuer, J. J. and Dalsace, F. (2002). "Do Make and Buy Decisions Matter? The Influence of Organizational Governance on Technological Performance". Strategic Management Journal, 23(9), pp. 817-833.

Levitt, B. and March, J. G. (1988). "Organizational Learning". Annual Review of Sociology, 14, pp. $319-340$.

Levy, D. and Terleckyj, N. (1989). "Problems Identifying Returns to R\&D in an Industry". Managerial and Decision Economics, 10(1), pp. 43-49.

Link, A. N. (1981). "Basic Research and Productivity Increase in Manufacturing: Additional Evidence". American Economic Review, 71(5), pp. 1111-1112. 
Link, A. N. (1982). The Transfer and Utilization of Technical Knowledge, chapter A Disaggregated Analysis of Industrial R\&D: Product versus Process R\&D. Lexington Books.

Link, A. N. (1990). "Firm Size, University Based Research and the Returns to R\&D.". Small Business Economics, 2(1), pp. 25-31.

Lokshin, B.; Belderbos, R. and Carree, M. (2008). "The Productivity Effects of Internal and External R\&D: Evidence from a Dynamic Panel Data Model.". Oxford Bulletin of Economics and Statistics, 70(3), pp. 399-413.

Loschky, A. (2008). "Reviewing the Nomeclature for High-Technology Trade. The Sectoral Approach.". Information and discussion STD/SES/WPTGS(2008)9, OECD.

Mansfield, E. (1980). "Basic Research and Productivity Increase in Manufacturing.". American Economic Review, 70(5), pp. 863-873.

Miravete, E. and Pernias, J. (2006). "Innovation Complementarity and Scale of Production". Journal of Industrial Economics, 54(1), pp. 1-29.

Mohnen, P. and Lépine, N. (1991). "R\&D, R\&D Spillovers and Payments For Technology: Canadian Evidence". Structural Change and Economic Dynamics, 2(1), pp. 213-228.

Niosi, J. (2000). "Explaining rapid Growth in Canadian Biothnology Firms.". Research Paper Catalogue No.88F00117MIE, No.8, Statistics Canada.

OECD (2002). Frascati Manual: Proposed Standard Practice for Surveys on Research and Experimental Development. Organization for Economic Cooperation and Development.

Pakes, A. and Griliches, Z. (1984). "Patents and R\&D at the Firm Level: A First Look". In $R$ \& $D$, Patents, and Productivity, National Bureau of Economic Research, pages 55-72. Chicago University Press.

Piga, C. A. and Vivarelli, M. (2004). "Internal and External R\&D: A Sample Selection Approach". Oxford Bulletin of Economics and Statistics, 66(4), pp. 457-482.

Revelt, D. and Train, K. (1998). "Mixed Logit with Repeated Choices of Appliance Efficiency Levels". The Review of Economics and Statistics, 80(4), pp. 647-657.

Rosa, J. M. ; Rose, A. and Mohnen, P. (2006). "Buying and Selling Research and Development Services, 1997 to 2002". Working Paper Catalogue No.88F0006XIE002, Statistics Canada, Ottawa. 
Schelling, R. and Gault, F. (2006). "Size and persistence of R\&D Performance in Canadian Firms 19942002". Science, Innovation and Electronic Information Division (SIEID) Catalogue No. 88F0006XIENo.008, Statistics Canada.

Schumpeter, J. (1934). The Theory of Economic Development. Harper \& Row, New-York.

Statistics Canada (1997-2006). "Research and Development in Canadian Industry". Survey, Statistics Canada, Ottawa.

Teece, D. J. (1984). "Economic Analysis and Strategic Management.". California Management Review, 26(3), pp. $87-110$.

Teece, D. J. (1992). "Competition, Cooperation, and Innovation : Organizational Arrangements for Regimes of Rapid Technological Progress". Journal of Economic Behavior and Organization, 18(1), pp. 1-25.

Teece, D. J. (1993). "Profiting from Technological Innovation: Implications for Integration, Collaboration, Licensing and Public Policy". Research Policy, 22(2), pp. 112-113.

Teece, D. J. (1996). "Firm Organization, Industrial Structure, and Technological Innovation.". Journal of Economic Behavior and Organization., 31(2), pp. 193-224.

Train, K. (2003). Discrete Choice Models Using Simulation. Cambridge University Press.

Uhlendorff, A. (2006). "From No Pay to Low Pay and Back Again? : A Multi-State Model of Low Pay Dynamics". Discussion Papers of DIW Berlin 648, DIW Berlin, German Institute for Economic Research.

Van Nguyen, P.; Laisney, F.; and Kaiser, U. (2004). "The Performance of German Firms in the BusinessRelated Service Sector: A Dynamic Analysis". Journal of Business and Economics Statistics, 22(3), pp. 274-295.

Veugelers, R. (1997). "Internal R\&D Expenditures and External Technology Sourcing". Research Policy, 26(3), pp. 303-315.

Veugelers, R. and Cassiman, B. (1999). "Make and Buy in Innovation Strategies: Evidence from Belgian Manufacturing Firms". Research Policy, 28(1), pp. 63-80.

Williamson, O. E. (1991). "Comparative Economic Organization: The Analysis of Discrete Structural Alternatives.". Administrative Science Quarterly, 36(2), pp. 269-296. 


\section{Appendix}

Table A1: Variable definitions

\begin{tabular}{|c|c|}
\hline Variables & Definitions \\
\hline & Dependent variables \\
\hline$(\mathrm{Q} / \mathrm{L})$ & Total revenues over total employment \\
\hline$\Delta(\mathrm{Q} / \mathrm{L})$ & Compound annual growth rate of revenues per employee \\
\hline Radical_R\&D & $\begin{array}{l}\text { Binary: } 1 \text { if the firm performs } R \& D \text { exclusively to develop new products, process or } \\
\text { technical services or to perform basic research }\end{array}$ \\
\hline & Independent variables \\
\hline$\left(\operatorname{Exp}_{-} \operatorname{Strat}_{-}(j) / Q\right)$ & $\begin{array}{l}\text { R\&D intensity: Ratio of R\&D expenditures dedicated to strategy }(j) \text { over total revenue, } \\
\text { where } j=m=\text { make, } m b=\text { make-and-buy, mbs=make-buy-and-sell, ms=make-and-sell }\end{array}$ \\
\hline$\left(\right.$ Strat $\left._{-}(j)\right)$ & Binary: 1 if firms $R \& D$ strategy $(j)$ is used, where $j=m, m b, m b s, m s$ \\
\hline$\Delta(\mathrm{L})$ & Compound annual growth rate of total employment \\
\hline$\Delta$ (Absorptive) & Compound annual growth rate of the ratio of $R \& D$ staff over total employment) \\
\hline Absorptive & R\&D staff over total employment \\
\hline Domestic & Binary: 1 if the enterprise is under domestic control \\
\hline Startup & Binary: 1 if $R \& D$ expenditure $\geq$ revenue \\
\hline Industry & $\begin{array}{l}\text { Binary dummies for grouped industries (High_tech; Medium_High_tech; } \\
\text { Medium_Low_tech and Low_tech) see appendix B for more details on the industrial } \\
\text { classification }\end{array}$ \\
\hline Year & Binary dummies for years \\
\hline
\end{tabular}


Table A2: Classification of industries by level of technology

\begin{tabular}{|c|c|c|}
\hline Level of technology & Industries & NAICS_2002 \\
\hline High_tech & $\begin{array}{l}\text { Pharmaceutical and Medicine; Communications } \\
\text { Equipment; Computer and Peripheral } \\
\text { Equipment;Aerospace product and parts }\end{array}$ & $334110 ; 334210-334290 ; 336410$ \\
\hline Medium_High_tech & $\begin{array}{l}\text { Other Chemical;Semiconductor and Other } \\
\text { Electronic Component;Navigation,Measuring, } \\
\text { Medical and Control Instruments;Other } \\
\text { Computer and Electronic Product;Electronic } \\
\text { Equipment,Appliance and Component;Motor } \\
\text { Vehicle and parts;All other Transportation } \\
\text { Equipment;Transportation and } \\
\text { Warehousing;Finance,Insurance and Real } \\
\text { Estate;Architecture,Engineering and } \\
\text { Related;Computer System Design and } \\
\text { Related;Management,Scientific and Technical } \\
\text { Consulting;Scientific Research and Development }\end{array}$ & $\begin{array}{l}325110-325999 ; 334410 ; 334511-334512 ; 334310- \\
334610 ; 335110-335990 ; 336110- \\
336390 ; 336510 ; 336611-336612 ; 336990 ; 481110- \\
493190 ; 521110-533110 ; \\
541310-541380 ; 541510 ; 541611-541690 ; 541710, \\
541720\end{array}$ \\
\hline Medium_Low_tech & $\begin{array}{l}\text { Oil and Gaz Extraction;Mining;Electric } \\
\text { Power;Other Utilities;Petroleum and Coal } \\
\text { Products;Plastic Product;Rubber } \\
\text { Product;Non-Metallic Mineral Product;Primary } \\
\text { Metal(Ferrous);Primary } \\
\text { Metal(Non-Ferrous);Fabricated Metal } \\
\text { Product;Machinery;Furniture and Related } \\
\text { Product;Other Manufacturing } \\
\text { Industries;Information and Cultural } \\
\text { Industries;Health Care and Social Assistance;All } \\
\text { Other Services }\end{array}$ & $\begin{array}{l}211113-221330 ; 562110,562210,562910,562920, \\
562990 ; 324110,324121-324122,324190 ; \\
326111-333990 ; 337110-339990 ; 511110-519190 ; \\
621110-624410 ; 541110,541120,541190, \\
541212-541213,541215,541410-541490,541810, \\
541820,541830,541840,541850,541860,541870, \\
541891,541899,541910,541920,541930,541940, \\
541990,551113-551114,561110,561210,561310, \\
561320,561330,561410,561420,561430,561440, \\
561450,561490,561510,561520,561590, \\
561611-561613,561621-561622,561710, \\
561721-561722,561730,561740,561791,561799, \\
561910,561920,561990,562110-562990 ; 611110, \\
611210,611310,611410,611420,611430,611510, \\
611610,611620,611630,611690,611710, \\
711111-919110\end{array}$ \\
\hline Low_tech & $\begin{array}{l}\text { Agriculture;Forestry and Logging;Fishing, } \\
\text { Hunting and Trapping; } \\
\text { Construction;Food;Beverage and } \\
\text { Tobacco;Textile;Wood } \\
\text { Product;Paper;Printing;Wholesale Trade;Retail } \\
\text { Trade }\end{array}$ & $\begin{array}{l}\text { 111110-115310;236110-238990;311111- } \\
323120 ; 411110-419190 ; 441110-454390\end{array}$ \\
\hline
\end{tabular}




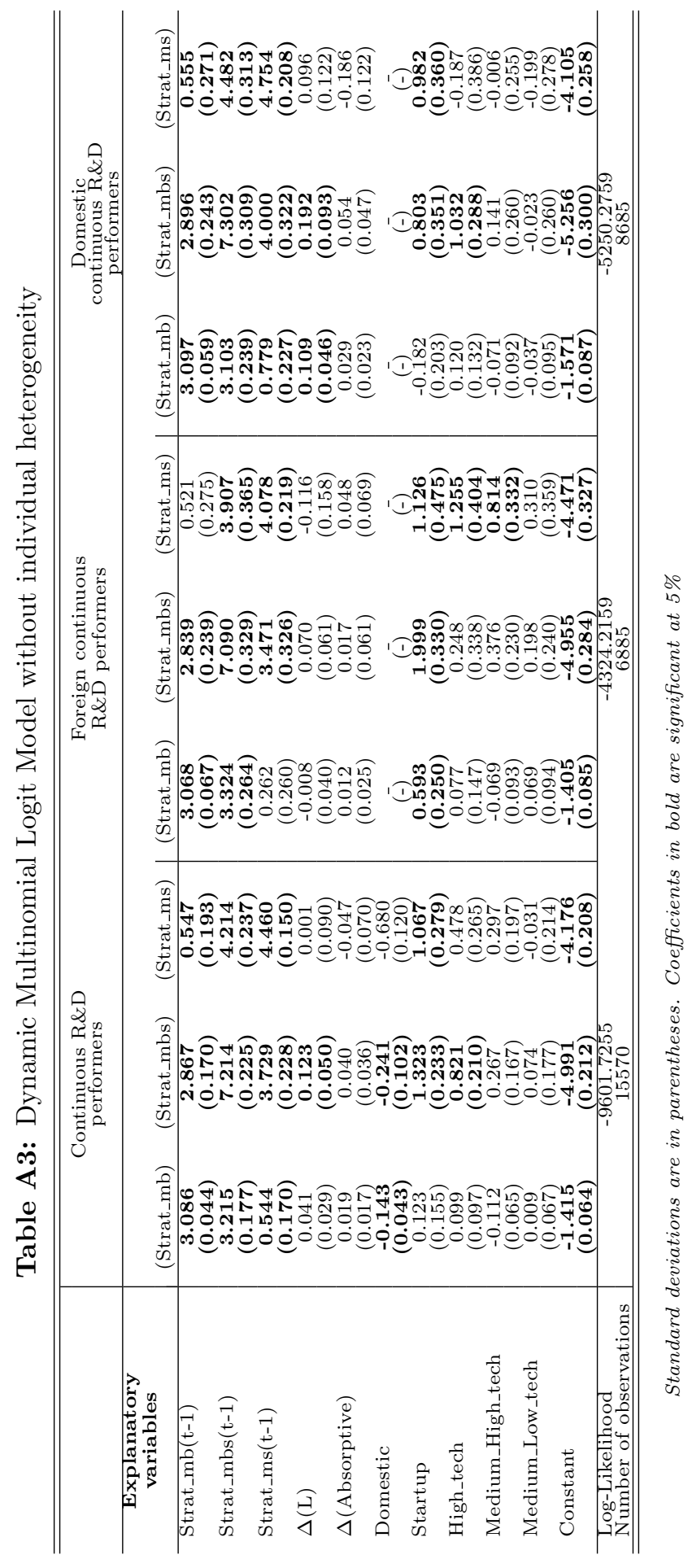

